\title{
BASIC EDUCATION REFORMS IN GUINEA: CONTEXT AND CONCERNS
}

\author{
Mamadou Saliou Diallo \\ medma06@gmail.com \\ University of Tsukuba \\ Japan
}

Copyright@2019 West East Institute

\begin{abstract}
This paper sets out to consider the context and concerns in educational reform through an examination of the achievements and difficulties encountered in attempts to develop basic education in Guinea. Yet, many are the countries around the world, and more specifically developing countries that have constantly cherished basic education development. This is obvious since all these countries, including Guinea, have-at one time or anotherundertaken reform in their education system. However, the real impact of these reform measures has been slow to be noticed, not only, with regard to the performance of the sector but also the improvement of human capital. As such, the paper proceeds to point out the prevailing issues in reform undertakings in Guinea's education sector. The study uses qualitative approach, and both primary and secondary sources to portray major national education intervention programs and their relative outcomes. However, it appears that the inability of the system to capitalize on previous efforts and gains presents a key challenge to ensure the sustainability of basic education development in the country.
\end{abstract}

Keywords: Basic education, education reform, developing countries, Guinea.

\section{Introduction}

Guinea, like many countries around the world, and more specifically developing countries, has constantly cherished education. Such an inclination for this sector is manifested in the continuous efforts made for its advancement. This is obvious since many if not all countries in the world have-at one time or another-undertaken reform in their education system. The motivations behind these reforms are driven by strong beliefs placed on education, which is viewed as a key factor in the socio-economic development of individuals, societies and countries at large.

This perception is further deepened and supported by modernization and/or development theorists. And this belief is later on endorsed by major international organizations-bi-and multi-lateral-intervening directly or indirectly in education development assistance. As such, development theorists considered reform in education as a crucial step for sustainable development, for improving education is perceived as a primary means of building human resources; which Harbison (1973:3) calls the "ultimate basis for the wealth of nations", more crucial to long-term sustainable economic growth than capital, natural, and material resources (Rondinelli, Middleton and Verspoor, 1990: 4).

In this respect, many developing countries including Guinea became more and more committed in developing their education system, primarily through basic education. Therefore, the improvement of basic education remains largely an absolute priority, especially in various national strategic development plans. Developing countries, being the most confronted with acute poverty and developmental issues, have made primary education an essential component in their development agenda. Hence, in view of translating these national aspirations, a series of reform programs has been rolled out in many educational systems. As such, alongside other world regions, sub-Saharan Africa has also made a seamless bet on the promotion of basic education.

Furthermore, over the last several decades, the pursuit of this ambition has benefited from the joint efforts of governments and development partners across the developing countries. While some progress has been made in a number of countries, much remains to be done to reach universal primary education of good quality. The fact is that most of these countries, although having experienced successive reform models, are up to now, still searching for 
approaches that would better respond to their real needs and expectations. Guinea is, in fact, such a typical subSaharan African country that has subscribed to all major global education reform programs. However, the country still struggles to ensure a general coverage of good quality and equitable educational services for all its citizenry.

Indeed, the key challenge facing Guinea's education system is to ensure the sustainability of reform interventions in the sector. From this point of view, a central question arises as to what is the inherent problem that prevents the numerous efforts made in the sector from redressing Guinea's educational system performance. This goes hand to hand to question the viability of the structures in charge of the sectoral governance. In all likelihood, it can be argued that the sector remains largely unable to capitalize on the various intervention efforts for it to become more effective and provide an efficient service delivery system, which is self-sustaining in many aspects of educational governance.

This paper is organized as follows. Section 2 offers a brief review of the literature. The methodological part is presented in section 3. Major educational intervention programs and their relative outcomes are portrayed in Section 4. Finally, Section 5 concludes the paper and draws some implications.

\section{Literature Review}

The debate on education reform encapsulates various accounts, which in fact reflect diverse perspectives. However, accounts on educational reform in the developing countries mostly evolved around two adjacent lips. On the one hand, stands discourse on reforms' instigators. Reference here is given to international assistance organizations, which began in the late 1970s and early 1980s to promote education reform, and their projects required significant changes in the structure and financing of education (Rondinelli, Middleton and Verspoor, 1990: 8). On the other hand, the rhetoric is rather oriented towards the commitment and capability of recipient countries in adopting and carrying out reform programmes successfully (Steiner-Khamsi, 2004, 2010; Moulton, Mundy, Walmond and Williams, 2001; Kingdon, 2002; Williams \& Cummings, 2005; Hirosato \& Kimura, 2009; Robertson et al. 2012; Verger, 2011).

However, in either case, it is posited that reforming education has been a major challenge for politicians, academicians and the business world in many countries as well as many national and international organizations, especially in the last two decades of the $20^{\text {th }}$ century (Baskan \& Erduran, 2009). Yet, the education policy-making process in the developing countries continues to mobilize new players-domestic and international actors (Hirosato and Kitamura, 2009; Verger, Novelli and Altinyelken, 2012). Thus, given this diversity of stakeholders involved in education reform, it is not surprising that their priorities in the sector differ in some respects. Hence, many are the views in the literature that denounce the conflicting attitudes among reform actors in advancing their mandates and/or interests (Samoff, 1999; Hirosato and Kitamura, 2009; Swift-Morgan, 2011). In this regard, the underlying assistance and cooperation [in education reform] are potentially conflicting interests between the economic and political goals, and the social and cultural values of the donor and those of the recipient country (Morales-Gomez, 1991).

Moreover, key players working under the mandates of aid agencies or national governments often influence education reform processes in the recipient countries. As such, it has been noted that international players possessing significant resources often set education agendas and define the priorities of countries, and at the same time impose certain policies via funding mechanism and aid conditionality (Verger, Novelli and Altinyelken, 2012; Hirosato and Kitamura, 2009; Swift-Morgan, 2011). This partly explains why developing countries, especially Less-Developed Countries, become highly dependent on foreign expertise, information and financing (Rose, 2007). In tandem with such a perspective, further views support this assertion in a similar tone, contending that "most developing countries lack the physical infrastructure and experienced, skilled professionals needed to assure successful results. Many lack strong institutions and organizations that are needed to carry out changes. They have few administrators with the ability to mobilize financial and human resources in a timely fashion. Most countries do not have planning processes that allow planners and administrators to learn from past experience" (Havelock and Huberman, 1977).

Taking this stand, a variety of reform initiatives, which are largely backed up by aid-agencies have been introduced with the aim to change the educational systems of Third World countries. However, it follows that "many of the education reforms borrowed from outside and imposed on developing countries may not only fail, but also cause unintentional harmful consequences of surprise outcomes" (Oplatka, 2018). What is more, "many education reform projects are designed by bureaucrats in the ministry of education, university professors, or foreign consultants who 
use standard professional solutions to education problems. Frequently their proposals do not reflect a real understanding of what teachers, parents, or students actually need or want. Planners often fail to conduct a needs analysis and ignore the requirements for mobilizing demand" (Rondinelli, Middleton and Verspoor, 1990: 8).

Furthermore, reform actors from education ministries and funding agencies designing or implementing reform programs are subject to certain tradeoffs. And this being first, whether to establish a balanced plan of the sectoral performance; getting more children to school (universal access) - [which aid agencies often prioritized], setting standards to help children get a reasonably good education (quality), and improving the management and administration of the system (capacity building) (Moulton, Mundy, Walmond and Williams, 2001). Or else, to operate a systemic change in the overall performance of the sector. Whatever the case, it is observed that in many sub-Saharan African countries, the educational reform is characterized by the domination of elite groups who either perceive that they have a vested interest in maintaining in their present form longstanding but possibly ineffectual functions of the educational system. [Often the status quo is] related to social selection and the legitimization of poverty or related to the consciousness and interests particular groups, due to their previous experience of education and the benefits they have obtained from it, which may not permit them to consider alternatives seriously (Alexander, 1997).

Likewise, in the case of Guinea, the various reform interventions in the education sector have merely improved its performance, especially at the basic education level. Thereupon, a general observation tends to attribute this failure to the leading nature of the technical assistance that Guinea benefited in formulating and implementing its education policies (AfDB, 2005). But also, the high transaction costs put on the shoulders of Guinea's education officials, who actually were supposed to implement the policies, turned out to be more concerned with meeting donor criteria than assessing Guinean needs (Walmond, 2002). In essence, the development of the education sector in Guinea has for the most part been pursued in a superficial way (inconsistent policy and means of action) and sometimes with a lot of amateurism, argued Labila Sonomou ${ }^{1}$ (Saouromou, 2017). What is most worrying about this effect is, first and foremost, the obvious inertia in the governance of the system that is up to date struggling to reinvent itself. But also and above all, the lack of a critical literature that can highlight the sector's notorious failings, and, at the same time, contributes to the formulation of new possible alternatives. Indeed, this article wants to be enterprising in this sense. ${ }^{1}$

\section{Methodology}

This study uses a case study and applies a qualitative research approach. The data sources comprise desk study of government policy documents and reports from aid agencies, individual semi-structured interviews, and homogenous focus groups of subject types. Also, observation of participants and reform settings/agencies provides additional invaluable information to this study.

\section{Reform Efforts in the Education Sector}

Successive governments in Guinea from 1958 to 2015 have all placed education as their top priority in the country's development agenda. This renewed commitment to the development of the sector was not adventitious but rather fueled by national vision and ambition. Like many other countries, the leaders who were in charge of Guinea's destiny understood the merits of education in the promotion of socio-economic well-being of the people and the country. Therefore, being convinced that the basis of real development goes through the qualification of a country's human capital, led them to favor wider reforms in the education sector. However, as educational reform refers to a change and/or shift in existing policies to engender a betterment of previous structures of the educational system, this has motivated related actions taken by Guinea's governments in the sector. Large-scale reform initiatives pertaining to education development in Guinea have revolved around three main intervention periods: the period after the country's access to (political) independence in 1958, followed by the change of regime in 1984, and then the advent of the global movement of EFA (Education for All) in the year 2000 with goals' achievement target in 2015.

\footnotetext{
${ }^{1}$ Mr. Labila Michel Sonomou, President of Lawyers without Borders in Guinea
} 


\section{Post-independence Initiative}

Shortly after Guinea's access to (political) independence in October 1958, the first regime to inherit the colonial power undertook policies geared towards breaking away from the previous colonial system (Diallo, 2016:5). To reach this end, the authorities under this regime decidedly initiated drastic policy change intended to remove all western types of education (i.e., Catholic church and French established schooling system) to introduce a more African mode of education based on a revolutionary and socialist educational philosophy (Rivière, 1965: 629; Corrie, 1988:278; Barry, 2010:94). The objective sought by Touré's regime in its educational innovation during the 1960s and 1970s was simply to rid Guinea of colonial influences and promote education for self-sufficiency (Walmond, 2002: 121). Thus, the provision in this regard is reflected in the constitution of 1958, [which] guarantees free, compulsory, and equal education to every citizen until the age of $15 .^{2}$

The effect of this policy coupled with various acute shortages_-administration, infrastructure, personnel, fund, etc.altogether resulted in the sectoral inefficiency up until 1984 (World Bank, 1990:2; Barry, 2010:94).

\section{SAP Intervention Initiative}

The advent of a new regime (military takeover) in 1984, occasioned however some change measures in the education sector. Two national conferences on educational matters were held in Conakry (Guinea's capital city) in 1984 and 1985. Several arrangements were put forward during these encounters. As a result, the most significant decision made was the discontinuity of eight national languages used previously as language of instruction and the reintroduction of French in the first grades (from $1^{\text {st }}$ to $3^{\text {rd }}$ grade) of primary school. This was the first major reform initiated by the new government, and it signaled a substantial departure from previous education policy (Walmond, 2002:121).

In line with this sectoral program reform, a more coherent and comprehensive educational intervention followed in 1987. With the collaboration of external partners, the government of Guinea adopted in 1989 an education policy statement-a structural adjustment in the sector-with goals that extend until the year 2000. The areas of intervention identified in this reform (PASE I \& II) relate to the expansion of public funding for primary education, increase in its access, improvement in quality and equity in its provision, as well as the management capacities of the department in charge of its service delivery by devolving the planning and management structures to local levels. However, expectations from this intervention fell short despite the growing support of partners to the sector; little progress was made in terms of access with serious internal and external efficiency issues (World Bank, 1995, 1999, 2002; Walmond, 2002; Back et al., 2003; Barry, 2010).

\section{Initiative under EFA}

The growing demand for good quality education and its equitable provision led Guinea, like many other developing countries, to subscribe to the tenets, goals and targets of EFA to be reached by 2015, with the program's goals being adapted to the country's needs and priorities (Midling et al., 2006: Appendix B-2). As the third reform initiated in its sector, "Guinea's EFA, was officially launched in 2002, covering a planning period of 12 years. The program emphasizes three major areas of intervention: access, quality and management—as a framework for technical and financial partners' interventions" (Midling et al., 2006:2).

According to the African Development Bank (2005:4), the provisions that guided this sectoral reform-“"the Government's sector policy-are based on the Education Policy Statement of September 1989, the National Education Orientation Law (1997), the recommendations of the World Education Conference (Jomtien 1990, Dakar 2000, etc.), and the MDGs". The main objective of this program, which is to achieve universal primary education, and equitable development of the entire education system, is reflected in the country's Poverty Reduction Strategy Papers, under the objective that seeks to increase the population's access to basic social services. In this respect, the government undertook extensive reforms at several levels (structural, institutional, financial and educational) (AfDB, 2005:4). However, the potential threats to the success of EFAP (Education For All Program) intervention rest on

\footnotetext{
${ }^{2}$ For further details please refer to the following link (retrieved on April 26, 2019): https://education.stateuniversity.com/pages/577/Guinea-EDUCATIONAL-SYSTEM-OVERVIEW.html
} 
"insufficient infrastructure, unevenness in institutional capacity, limited budgetary and qualified human resources" (Back et al., 2003; Midling et al., 2006; World Bank, 2018).

\section{Performance Implications in the Sector}

In fact, it appears worthwhile determining first what basic education represents in a given educational system. This would help to better determine the performance toward its development. The Global Monitoring Report of the UNESCO-IBE (2007b) synthesizes the results of analysis of 113 national definitions of basic education in relation to the formal education system. This synthesis reveals that "in two-thirds of countries, basic education definition follows the International Standard Classification of Education (ISCED) and covers primary and lower secondary education. While, in the remaining third, the term is equivalent to primary education only or to primary plus some preprimary or secondary education" (see table below).

Table 1: National definitions of basic education

\begin{tabular}{|l|l|}
\hline \multicolumn{1}{|c|}{ Basic education definitions (number of countries) } \\
\hline Primary education only (8) & $\begin{array}{l}\text { Cape Verde, Ethiopia, Guinea-Bissau, Haïti, Maldives, } \\
\text { Mozambique, Nicaragua, Portugal }\end{array}$ \\
\hline $\begin{array}{l}\text { Primary education plus at least one year of pre-primary education } \\
\mathbf{1 7})\end{array}$ & $\begin{array}{l}\text { Albania, Bhutan, Botswana, Brazil, Burkina Faso, Burundi, } \\
\text { Cameroon, Democratic Republic of the Congo, Djibouti, } \\
\text { Ecuador, Guinea, Macao(China), Mexico, the Niger, Panama, } \\
\text { Tunisia, Zimbabwe }\end{array}$ \\
\hline $\begin{array}{l}\text { Primary education plus lower secondary \& at least one year of } \\
\text { upper secondary education } \quad \mathbf{7})\end{array}$ & $\begin{array}{l}\text { Argentina, Brazil, Republic of Korea, Oman, Philippines, } \\
\text { Slovenia, Saint Lucia }\end{array}$ \\
\hline $\begin{array}{l}\text { Primary education plus some pre-primary \& lower secondary \& } \\
\text { some upper secondary education (5) }\end{array}$ & \begin{tabular}{l} 
China, Kenya, Myanmar, Peru, Thailand \\
\hline Primary \& lower secondary education (76)
\end{tabular} \\
\hline
\end{tabular}

Source: UNESCO-IBE (2007d)

Table 1 shows that basic education in Guinea's education system encompasses both pre-primary and primary [formal] education. However, youth and adults training programs have been included within the recent effort dedicated to basic education diffusion in the country, which actually falls under the EFA general goals and targets.

\section{Early Childhood Education}

Against this background, it is important to retrace Guinea's progress in the provision of basic education services to its young children. At first, it is necessary, however, to take a look at the educational cycle dedicated to early childhood to better understand its overall implication on the provision of services. Indeed, preschooling aims to develop all potentialities and abilities-physical, psychomotor, cognitive and socio-educational-existing in the young child while preparing him/her to approach with serenity the primary education level.

Moreover, it also becomes clear that the development of pre-school education facilitates the acquisition and sustainability of basic education through the direct and positive effect it confers to children in terms of prerequisites-language acquisition and early literacy. As a result, this teaching cycle contributes, among other things:

-to promoting equal opportunity between children with different socioeconomic characteristics and especially to the improvement of gender equity;

-to maintaining and improving educational quality, reducing repetition and drop-out, thus representing an effective means of reducing the cost of internal inefficiency of the system.

Due to its merit and its inherent status, pre-primary education is recognized as such as a natural and universal right. As such, many countries, especially Westerns nations, have given priority and universalized this level of education, while the countries of sub-Saharan Africa in general and Guinea in particular still lag behind. However, it must be emphasized that the country is committed to respecting, defending and promoting this sub-sector as a due right of its 
younger children. Yet, despite this commitment, the country is facing significant problems that inhibit Guinea's children from fully enjoying this right, more precisely, their right to education, as access to preschooling service is formally recognized as a sub-level of education in Guinea's education system. However, prior to the advent of the global campaign for basic education in the year 2000, the supply of public preschool was almost non-existent in Guinea. In fact, this trend is still far from being reversed despite repeated calls for concrete actions in favor of this sub-sector. To date, its coverage remains very disparate across the country with a high concentration of educational institutions in urban areas, thus reflecting a remarkable absence of public preschool institutions especially in the interior. In fact, out of 1746 educational institutions, only two are public and all are situated in Conakry (the capital city); 190 are community-based and the rest are private (cf. Statistical Yearbook 2014-2015).

As such, it appears that the system relies mainly on the private sector, which comprises more than $81 \%$ of the preschool total enrolment and $80.8 \%$ of educational institutions. Community institutions provide the rest. Public institutions are non-existent in the countryside. To date, Conakry still has more than half (52\%) of institutions that host about $53 \%$ of pre-school enrolment. The N'Zérékoré region follows with more than a quarter of the facilities in 2009. In all, these two regions account for $78 \%$ of preschool establishments. The regions of Faranah and Kindia have also made strides in community education. However, the regions where preschool institutions are weakly implanted are Labé, Mamou, Kankan and Boké.

Figure 1: Distribution of preschool institutions by status in 2016

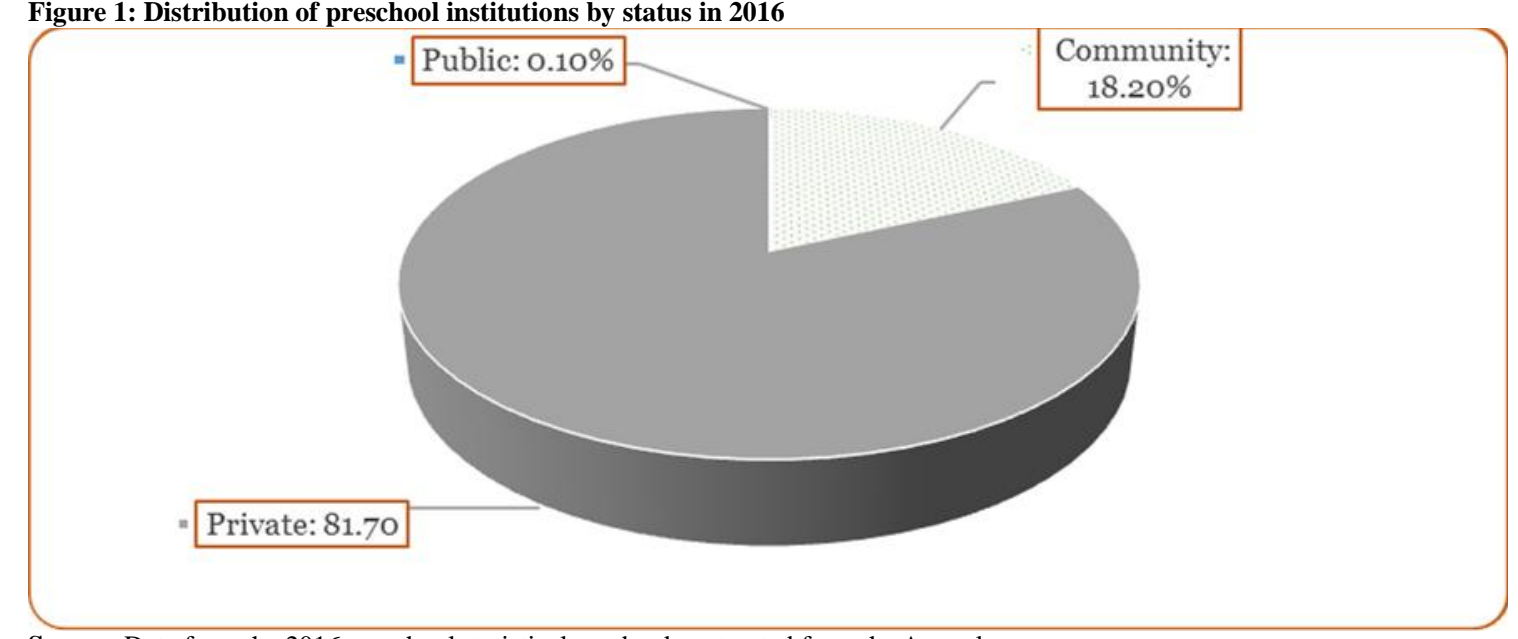

Source: Data from the 2016 preschool statistical yearbook, extracted from the Annual

Performance Report of Guinea's Ministries of Education, 2017

Overall, the situation deriving from the limited number of facilities and the significant imbalance in their availability partly explains the low preschool enrolment rates over the years in Guinea. As previously indicated, before the inception of the EFA program, the rate of preschool enrolment was below five percent. Although data is lacking, the compiled estimates of gross enrolment rates show a very weak progression before the 2000s. This trend accelerated thereafter to show encouraging progress in crossing the proportion of five percent and giving a glimpse of an evolutionary growth (see the table below).

As Table 2 shows, the coverage of preschool education in recent years is still very low in Guinea-8.4\% by 2015, one of the lowest rates in the sub-region (11\% on average). At the national level, Conakry has the highest gross preschool rate. However, other regions like N'Zérékoré and Kindia have made some efforts owing to the support of associations and NGOs in the development of early childhood (Figure 2). Although the Social Protection Ministry (MASPEE) regulates the provision of preschool services, The Guinean Government does not mandate this level of education dedicated to children aged 3 to 6 years old. Up until now, it remains established that most of the existing early childhood care and development (ECCD) services are provided by either private entities or communities, through associations and/or NGO initiatives. 
Table 2: Evolution of enrolments at the preschool level in Guinea

\begin{tabular}{|c|c|c|c|c|c|}
\hline Year & $\begin{array}{c}\text { Total } \\
\text { number of } \\
\text { pupils }\end{array}$ & Gross enrolment Rate & Year & $\begin{array}{c}\text { Total } \\
\text { number } \\
\text { of pupils }\end{array}$ & Gross enrolment Rate \\
\hline $1990-1991$ & --- & --- & $2005-2006$ & 80217 & 6.1 \\
\hline $1993-1994$ & 10260 & $0.7 \%$ & $2006-2007$ & 88918 & 6.8 \\
\hline $1994-1995$ & 15908 & $1.2 \%$ & $2007-2008$ & 99819 & 7.3 \\
\hline $1995-1996$ & 21850 & $1.6 \%$ & $2008-2009$ & --- & 7.5 \\
\hline $1996-1997$ & 23736 & $1.8 \%$ & $2009-2010$ & --- & --- \\
\hline $1999-2000$ & --- & --- & $2010-2011$ & --- & --- \\
\hline $2000-2001$ & --- & --- & $2011-2012$ & --- & --- \\
\hline $2001-2002$ & --- & --- & $2012-2013$ & -- & 8.4 \\
\hline $2002-2003$ & --- & ---- & $2013-2014$ & -- & \\
\hline $2003-2004$ & 67881 & 5.2 & $2014-2015$ & 152093 & \\
\hline $2004-2005$ & 74582 & 5.7 & &
\end{tabular}

Source: Data compiled from RESEN Guinée 2004; ROCARE/ERNWACA 2010; SABER 2013; Guinea/MOE 2014-2017-2018.

In fact, such an undertaking is in itself a good thing since it helps to eliminate existing disparities between rural and urban areas.

Figure 2: Student enrolment in preprimary programs by region

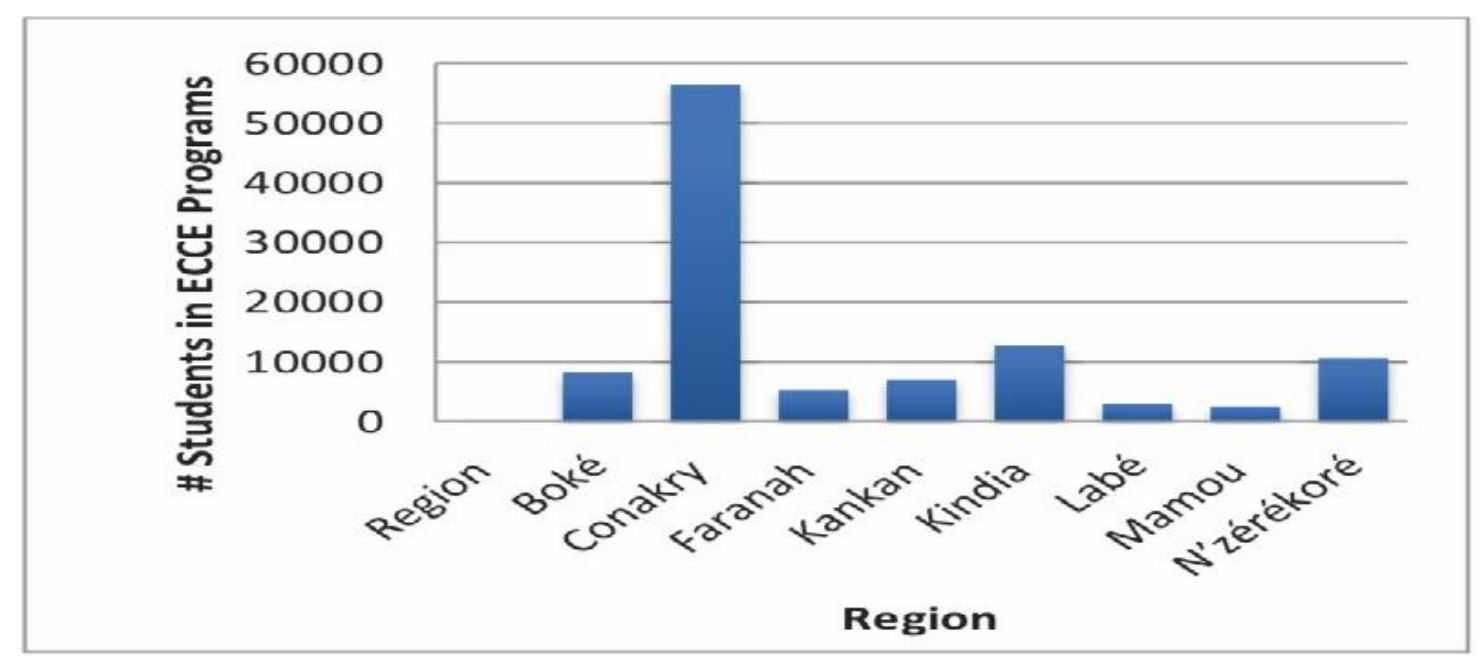

Source: MASPFE, Statistics on Preprimary Education, 2010-2011 (extracted from the World Bank (2013:13) SABER Country Report).

Nonetheless, it should be emphasized that further effort is certainly required from all actors involved in ECCD services provision, however, a greater commitment of the government is much more needed to spearhead the development of this sub-sector. In essence, the harmonization of efforts in this direction necessarily requires an operational framework. This will not only define and guide the intended preschooling plans and programs but also, and above all, better regulate the activities of intervening actors. As for now, it is not quite certain that the government can provide a substantial number of centers providing ECCD services throughout the country. Because not only is the number of unregistered centers unknown but also there are various types (Jaramillo \& Tietjen, 2001:16) With regard to the types of ECCD centers available in Guinea, they vary according to their location. Nevertheless, these centers range from crèches, childcare centers, nursery schools, and kindergartens to community education centers (CEC).

Moreover, the most common types of ECCD nowadays in Guinea are the jardin d'enfants (kindergartens) with a percentage share of $74.6 \%$ (targeting children from the age of two). Then, this is followed by the community education centers with a share of $10.4 \%$, which are recent initiatives financed by NGOs such as UNICEF, Action-Aid and many others and operated by local community organizations. There are also the école maternelle (nursery schools) with $4.10 \%$ share and enrolling children of three to six years old (Jaramillo \& Tietjen, 2001:16; World Bank SABER report, 2013: 13) 
Table 3: Number of ECCE centers by type and region

Source: MASPFE, Statistics on Preprimary Education, 2010-2011

\begin{tabular}{|l|c|c|c|c|c|}
\hline Region & Crèche & $\begin{array}{c}\text { Childcare } \\
\text { Centers }\end{array}$ & $\begin{array}{c}\text { Nursery } \\
\text { School }\end{array}$ & $\begin{array}{c}\text { Kinder- } \\
\text { garten }\end{array}$ & CEC \\
\hline Boké & & & 4 & 46 & 6 \\
\hline Conakry & 24 & 6 & 1 & 569 & 0 \\
\hline Faranah & & & & 24 & 28 \\
\hline Kankan & & & 5 & 46 & 20 \\
\hline Kindia & 1 & 1 & 2 & 133 & 24 \\
\hline Labé & & 1 & 4 & 35 & 6 \\
\hline Mamou & 1 & & 2 & 19 & 11 \\
\hline N'zérékoré & 3 & 1 & 33 & 57 & 34 \\
\hline Total & 29 & 9 & 51 & 929 & 129 \\
\hline \% Share & $\mathbf{2 . 3 \%}$ & $\mathbf{0 . 7 \%}$ & $\mathbf{4 . 1 0 \%}$ & $\mathbf{7 4 . 6 \%}$ & $\mathbf{1 0 . 4 \%}$ \\
\hline
\end{tabular}

Additionally, it should be pointed out that despite the variety of these centers and their increased number in recent years, the majority of ECCE facilities are still located in urban and peri-urban areas, which put children in rural areas at a disadvantage (World Bank/SABER report, 2013: 13). Another disparity in the preschool provision relates to gender equity. In this respect, it was noted that the preschooling rate of girls remains above that of the boys. As such, the gross preschooling rate of girls in 2008 was $7.8 \%$ while that of boys was $6.5 \%$. Further concern with regard to pre-primary education development in Guinea has to do with differences in socioeconomic groups. Under the current situation, children with disabilities and/or those from poor or marginalized families have limited access to preschool education services. This state of affairs deserves special attention. If not, the government's efforts to increase preschool enrolment to 30 percent by 2020 and expand coverage in rural areas may be unattainable.

\section{Primary Education}

Elementary education has long been a priority choice in the Guinean education system. Of all the reforms envisaged in the education sector, the primary level has always been at the center of major concerns and plans. This has made many people more often than not confuse primary schooling with basic education, as is especially the case in Guinea. In any case, given the implication of this education sub-sector in the process of human and economic development, the Guinean government under the impetus of recent educational reform waves, also initiated measures in this direction. To support the development of primary education in the country, many technical and financial partners from bi- and multi-lateral organizations displayed their interest and willingness to assist the government. Thus, following this renewed commitment, not only has the education sector been identified as a national priority but also primary education was made compulsory for all children in the country.

In Guinea, elementary education lasts six years. Children are admitted at the age of 7, sometimes older in the countryside. As stated previously, primary education is compulsory and is structured in three sub-cycles: the preparatory course (CP1 and CP2), the elementary course (CE1 and CE2) and the middle course (CM1 and CM2). A certificate of elementary studies (CEPE) sanctions the completion of this level of education. Moreover, under article 10 of the Framework Act on Education in Guinea-Law No. L/97/022/AN of 19 June 1997—it is expected that pupils completing this level be equipped with basic labor market skills, since the law states that the purpose of elementary education is to:

- awaken the child's spirit through school exercises in order to allow the emergence and development of his/her abilities;

- ensure his/her physical, intellectual, moral, civic and aesthetic training and to awaken his/her initiative and critical sense;

- prepare for his/her gradual and harmonious integration to his/her environment by giving him/her the means to either access a secondary, general, technical or professional school, or to insertion into active life;

- rehabilitate manual work as a factor of development of the intelligence and as a base of future insertion in the economic and sociocultural environment, thanks to a close liaison between the school and the socio-educational 
environment.

In order to translate this ambition into reality, the Guinean Government, with the support of development partners, has undertaken major reform programs in the education sector. Therefore, various education plans and programs have been formulated and implemented. The most recent of these initiatives date from the second half of the 1980s. These initiatives refer to the Adjustment Program in the education sector (PASE), the Education for All (EFA) program, and the education sector program (PSE). Though much effort has been made, registered results are considered as being far below expectations. In this respect, a vivid recollection of the reform intervention in the country posits that "back in 1985, an analysis of Guinea's educational system revealed the need for sweeping changes in the system's structures and content, as well as its aims. The Government initiated reforms that led to the adoption of an Education Policy Statement in 1989" (Republic of Guinea, 2002: 33). Additional provisions have also backed the government initiatives in the sector such as the National Education Orientation Law (1997) and the recommendations of the World Education Conferences (Jomtien 1990, Dakar 2000, etc.) (AfDB, 2005:4). These various reform initiatives are deemed to have a common vision that falls within the framework of the MDGs, the EFA program and the Poverty Reduction Strategy (PRS).

Overall, the actions taken following these reform initiatives have more or less contributed to the achievement of some results. In terms of access to education, the gross enrolment ratio increased from 26.81 percent in 1990 to 57 percent in 2000. The gross enrolment ratio for girls stood at 44.3 percent in 2000, as opposed to 7.3 percent in 1990 (Republic of Guinea, 2002: 33). The youth literacy rate in the same period was estimated around 25 percent. The introduction of the EFA program in the early 2000s also boosted efforts to improve access to education in the country. Nonetheless, "the gross enrolment rate has stagnated around 79 percent since 2007 and at 70 percent for girls. In rural areas, the rate was 60 percent. The disturbing fact is that the dropout rate rose from 5.9 percent in 2007 to 11.6 percent in 2010, bringing down the primary completion rate to 57 percent in 2010" (AfDB, 2011: 5). As for the net primary enrolment rate, it rose from 53.3 percent from 2002 to 66.7 percent in 2013. During the same period, the primary completion rate went from 40.4 percent to 61.9 percent (United Nations Economic Commission for Africa, 2016:14).

Furthermore, the Economic Commission for Africa (2016) went on to indicate, "Net enrolment of girls was 69.4 percent in 2013, compared with 80.7 percent for boys, with an estimated gender parity index of 0.85 ". Adult literacy rose from 28.8 percent in 2002 to 31.0 percent in 2015. However, universal basic education advocated in the MDGs and the EFA's main target by 2015 has yet to be reached in Guinea. The latest indicators show an increase in the gross enrolment rate from 78.0 percent in 2010 to 97 percent in 2016; an increase in primary completion rate from 56.6 per cent in 2010 to 67 percent in 2016 (Republic of Guinea, 2018:13).

Figure 3: Educational performance in Guinea and selected comparator countries, 2014

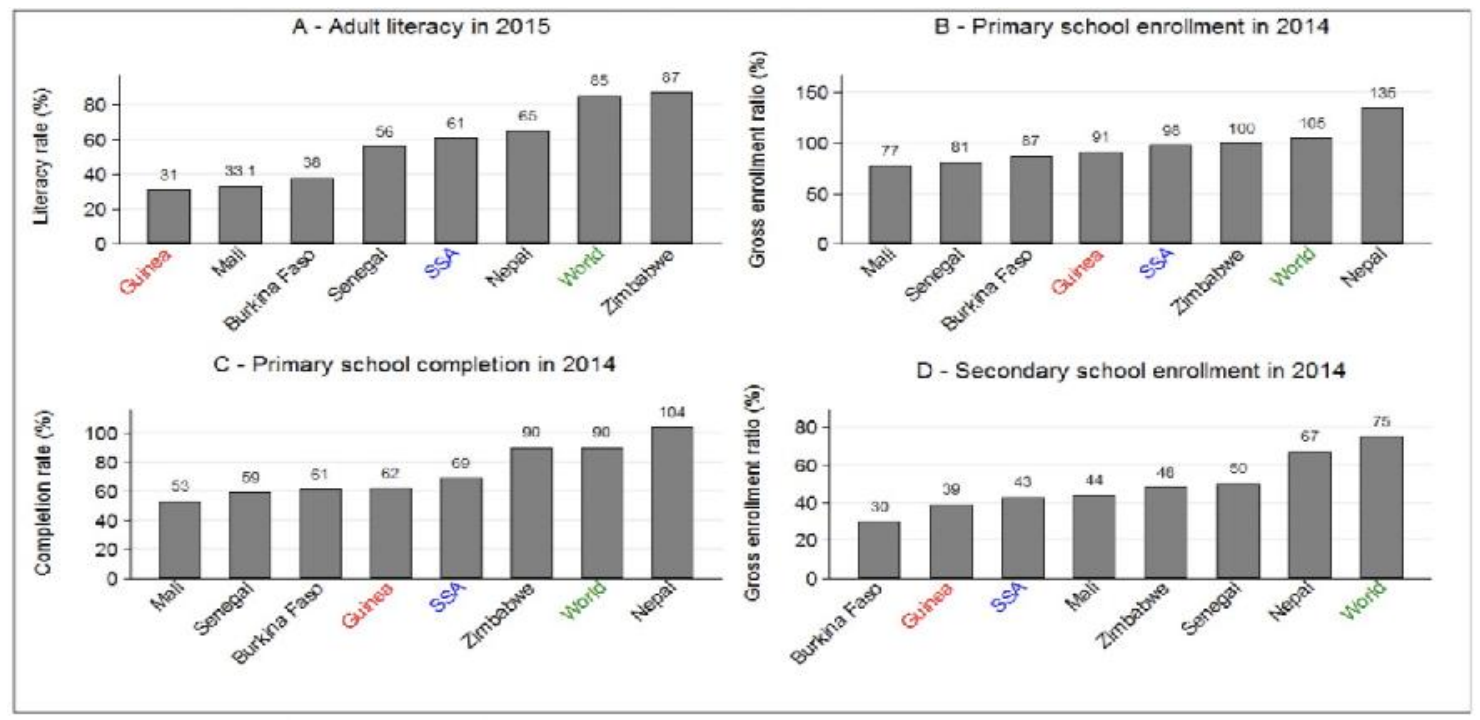

Source: World Development Indicators (extracted from the WB Systematic Country Diagnostic) 
Despite the quantitative gains made over the last three decades, especially in terms of expanding access to education, the provision of basic education still faces major problems in the country. As such, the sub-sector remains confronted with quality, equity and efficiency issues. Important challenges to achieve primary education for all and to improve the quality of basic education are among others:

(i) the mismatch between supply and demand, which is reflected in the inadequate capacity of the Guinean education system, mainly in rural areas and the plethora of urban classrooms; (ii) persistent disparities (gender and area) and low access of children to school (30\% of those of school age are out of school) [see Table $4 \&$ Figure 4]; (iii) the shortage of teachers and the misallocation of those available between geographical areas and urban and rural areas of residence despite recruitment made in 2017; (iv) the low quality of teaching and learning due to, among other things, insufficient academic and professional capacity of teachers and textbooks, (v) shortcomings in teacher training policy (vi) the inadequacy of the training provided with the real needs of the labor market; (vii) the lack of funding for the education sector (average 3.7\% of GDP compared with $4.5 \%$ in the sub-region) and (viii) the low internal and external efficiency of the system (Republic of Guinea, 2018:13).

In a first step, Table 4 better illustrates the disparities existing between genders and areas in the provision of education.

Table 4: Guinea: Gross School Enrolment Ratio by Region and by Gender

\begin{tabular}{|l|c|c|c|c|c|c|}
\hline \multirow{2}{*}{ Regions } & \multicolumn{3}{|c|}{$1998 / 1999$} & \multicolumn{3}{c|}{$1999 / 2000$} \\
\cline { 2 - 7 } & Girls & Boys & Total & Girls & Boys & Total \\
\hline Conakry & 76.8 & 96.6 & 85.5 & 83.1 & 102.4 & 92.5 \\
\hline Boké & 38.4 & 68.4 & 53.1 & 41.9 & 70.7 & 56.5 \\
\hline Faranah & 30.2 & 62.8 & 46.1 & 38.0 & 71.5 & 54.4 \\
\hline Kankan & 28.3 & 59.9 & 43.8 & 30.6 & 57.8 & 43.9 \\
\hline Kindia & 36.4 & 68.0 & 51.9 & 39.5 & 67.1 & 53.0 \\
\hline Labé & 29.9 & 46.4 & 37.9 & 37.9 & 54.0 & 45.8 \\
\hline Mamou & 26.7 & 51.7 & 38.9 & 36.0 & 61.8 & 48.7 \\
\hline N'Zérékoré & 40.0 & 75.3 & 57.2 & 38.1 & 65.5 & 51.5 \\
\hline National & 39.9 & 67.6 & 53.5 & 44.3 & 69.7 & 56.7 \\
\hline
\end{tabular}

Source: MEPU/EC (Ministry of Pre-University and Civic Education)

Following the recent reform in the sector, the changes that have occurred in the provision of primary education are reflected in Figure 4.

Figure 4: Evolution of the gross primary admission rate between 2015 and 2016

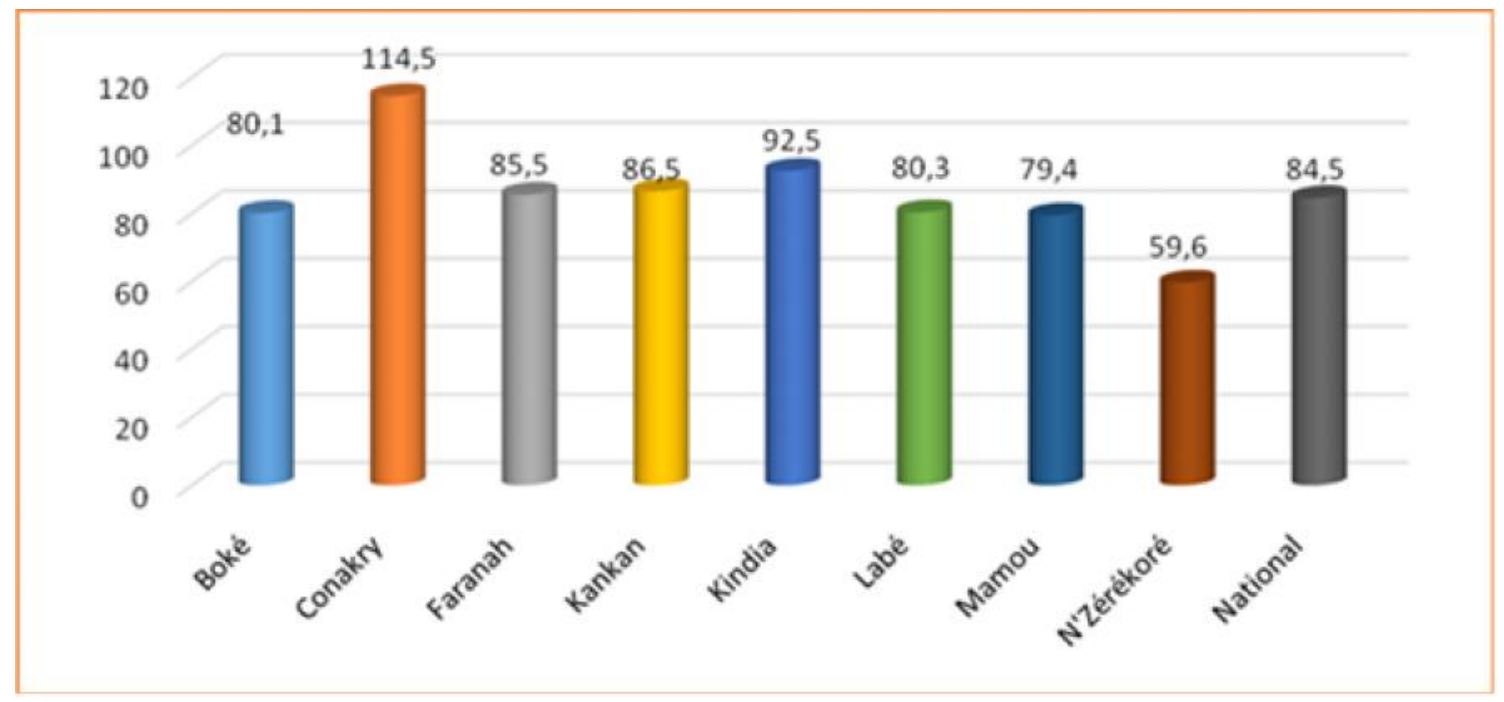

Source: Primary Education Statistical Yearbooks 2016 (Ministry of Education) 
Against all expectations, the gross enrolment rate observed in recent years presents important disparities among regions. This evolution shows that in the region of Faranah (85.5\%), Kankan (86.5\%), Kindia (92.5\%) and Conakry $(114.5 \%)$, the trend exceeds the national average (84.5\%). However, the regions of N'Zérékoré (59.6\%), Mamou (79.4\%), Boké (80.1\%) and Labé (80.3\%) remain below the national average, although in most of these regions the dynamics of schooling tend to increase (Republic of Guinea, 2017:23).

In short, this disparity observed within the country clearly demonstrates Guinea's educational weak performance as compared to the average in its sub-region. A summary of the sectoral status derived from the World Bank's Systematic Country Diagnostic (SCD) is quite alarming. The observation reveals that:

The literacy rate is 30 percent, one of the lowest in the world. School enrolment and completion rates are relatively low compared to the average for sub-Saharan Africa. Inadequate financing, a concentration of teachers in Conakry, a lack of appropriate teaching skills, deteriorating infrastructure, and insufficient planning are among the constraints to improving the educational system. Public spending on education was 2.6 percent of GDP in 2014, which is close to half the average for sub-Saharan Africa (4.6 percent) and low-income countries. (4.2 percent) (World Bank/SCD, 2018: xiii)

From the above-mentioned flaws, a possible explanation of drivers or inhibitors to Guinea's education system performance may reside in its institutional arrangement, hence the need to direct a deep inquiry into the system's structures, its usual operation and overall functioning, since a general understanding posits that "quality and equity in education provision is determined by how well the institutional and organizational architecture of the education system, as a whole, operates and functions. This concerns not just the quality of the teaching force, or the classroom learning environment, but also reliable research, planning, budgeting, management and administrative processes at all levels and the dependable release of funds for education sector policies and priorities" (UNESCO/CapEFA, 2011: 115).

\section{The Sector Governance Improvement Measures}

The various inefficiencies noted in the system deserve much attention. So far, the constraints related to the low performance of the system (limited access, quality and equity) are compounded by poor management of the system, and attributable mainly to weak technical and institutional capacities (AfDB, 2005:1). In fact, such a mediocre performance of the education sector derives from a long-lasting failure in governance. To ascertain the real causes of this situation, the country's historical legacy provides an evocative background on this setback. Obviously, Guinea has had a very rich and turbulent socio-political past that determines the country's current institutional challenge. The very first causal roots of these shortfalls are diverse and emanate from entrenched conflicting dynamics and class struggle. For example, it is argued that "the legacy of poor governance inherited from colonial powers led to a mismanagement of [...] resources, institutional fragmentation of the government, a weak social contract and rule of law, and low and ineffective public [sector management]" (World Bank/SCD, 2018:1). The related consequences of this state of affairs have been the lack of coherence, the lack of a comprehensive vision and the lack of coordination among the various players in the education system (Republic of Guinea, 2017:39).

Moreover, the political dynamic in Guinea witnessed long authoritarian ruling regimes that maintained their powers through allocation of public resources to their supporters (World Bank/SCD, 2018:2). This state of affairs, characterized by a fierce competition over the exercise and control of power, has created room for unconstitutional practices, whereby, under this complex political economy of rent seeking and history of opaque deals prospered a winner-takes-all mindset with a quasi-non-existent power sharing culture. This long history of personalized and politicized state system has also created a profound structural deficit in Guinea. Patterns of the French colonial regime, Sékou Touré's politicized one-party state and Lansana Conté's personalized regime still influence the country's current governance system (World Bank/SCD, 2018:2). Such a longstanding political dynamic at the uppermost levels of the state ended up distorting the institutional integrity. As a result of this structural deficit, the institutional arrangement does not provide a viable framework for adequate checks and balances.

What is more, this institutional and organizational cacophony has allowed considerable overlap of duties among a multiplicity of agencies, a situation that also contributed to blurring the lines of command. As a result, this gave rise to inconvenient practices such as clientelism, corruption, nepotism, etc., and for such practices to spread throughout 
public sector services. This ultimately deepened the public mistrust of state institutions. As such, this apparent sectoral disorder rightly manifested itself in Guinea's educational arena whereby, "several ministries have joint responsibility for the sector, making it difficult to manage the system because of lack of coordination and follow-up of actions; this affects management efficiency and quality control" (AfDB, 2005:3). With respect to such basic education diffusion, it is argued that "a quality education system is one that delivers a good education both equitably and efficiently. In this regard, the allocation, management, and use of resources are [not only] important dimensions and determinants of a high-performing educational and training system" (World Bank/CSD, 2018:83), but also, and still more importantly, the choice of policies and strategies and their effective implementation are crucial for the success of drastic reforms. However, the basic education sub-sector, as it currently stands, "remains plagued by low and uneven access, poor quality, weak teacher competencies, deteriorating infrastructure, uneven capital expenditures, inadequate financing, and a lack of planning" (World Bank/CSD, 2018: ibid).

\section{Conclusion}

Education reform initiatives have long been insufflated into Guinea's education sector with the intent to achieve improved socio-economic gains. However, the policies supporting these reform programs have been too ambitious, and consequently have lacked proper means for implementation. In view of the dilemma surrounding the reform of basic education in Guinea, this study has attempted to reveal the milestones that have already been set. Also and most importantly, the study highlighted the various issues that this sub-sector is constantly facing, for the sustainability of interventions and their achievements in the education sector are still suboptimal. And this despite an increasingly important mobilization of development partners, which together, with the government of Guinea have so far made undeniable efforts. All this, with the intent to expand access to basic education, improve the quality of teaching and learning, and strengthen management capacity for better education service delivery.

Moreover, to reach the above goals, successive national education development programs and reform policies have been implemented, including the Education Sector Adjustment Program (PASE I \& II from 1990 to 2000) and EFA program from 2002 with its target year in 2015. Therefore, the key lessons that result from these interventions are much dimensional. From a structural standpoint, the elementary level of education has not benefited from coherent actions in its development process. As proof, pre-school education has long been marginalized and it is only very recently that it has received due attention. At the primary level, which has often been at the center of all interventions, the registered results still remain below the real expectations, because the increase in the gross enrolment rate is at the expense of the quality of education. Against the backdrop of this poor performance lurks the shadow of institutional and organizational problems. Institutional governance is implicated because the process of the reform policy design is that of a centralized type, which quite often is imposed rather than introduced following a thorough consultation. Equally, the enactment and implementation of the policy rest largely upon a top-down approach.

Furthermore, strategies to improve the performance of the sector often stumble against a complex structural organization. This organizational barrier increases coordination problems among the various stakeholders, affecting the cohesive arrangement of the interventions and thus weighing down the administrative and management procedures of the sector. As such, the capacity gap gets widened despite intense and concerted efforts to address the sectoral planning and management weaknesses. Both at the pre-school and elementary school levels, service delivery is strangled by the lack of a proper institutional framework. In extenso, this therefore engenders all the shortcomings that the sector faces, namely, a lack of infrastructure, technical support, qualified administrative and teaching staff, material and financial resources. Unless drastic and systematic reform initiatives are further taken to insufflate a substantial change of mindset and the behaviors of larger target groups, basic education development in Guinea will continue to strive longer before it sees the end of the tunnel.

\section{Acknowledgements}

The author would like to express his great appreciation to Professor Timur Dadabaev for his guidance and constructive feedback on this paper. In addition, special thanks are extended to Professor Leslie Tkack-Kawaski and Professor Nathan Gilbert Quimpo for their useful comments on this work. A particular thank is also dedicated to Mamoudou Bah for his concern and support to this project. Finally, a deep appreciation is conveyed to the Honjo International Scholarship Foundation for their overall assistance. 


\section{References}

Abrahamsen, R. (2000). Disciplining democracy: development discourse and good governance in Africa. London: Zed Books.

African Development Bank. (2005). Basic education development support project, education project IV. Appraisal Report, Republic of Guinea.

African Development Bank. (2011). Republic of Guinea: Country Strategy Paper 2012-2016. Regional Department, West 2 (ORWB).

Agence Nationale de Promotion de la Bonne Gouvernance \& de Lutte contre la Corruption (2011). Etat de la gouvernance et de la corruption en Guinée. Rapport d'activité. Ministère du Contrôle Economique et Financier.

Al'Abri, K. (2011). The impact of globalization on education policy of developing countries: Oman as an Example. Literacy Information and Computer Education Journal (LICEJ), 2(4), 491-502.

Alexander, D. (1997). Problems of educational reform in Zambia. Conference proceedings, pp. 77-103, SCUTREA. Retrieved on August 28, 2019 from: http://www.leeds.ac.uk/educol/documents/00002618.htm

Babu S. C. \& Sengupta, D. (2006). Capacity development as a research domain:

frameworks, approaches, and analytics. International Service for National Agricultural Research (ISNAR) Division, Discussion paper 9.

Back et al. (2003). The evaluation of the African girls' education initiative country with case study Guinea/Conakry (1994-2004), Child development programme. UNICEF.

Barry, A. (2010). Understanding the Guinean education system: evolution and some performance indicators. African educational Research Network. The African Symposium 10(1), 91-102.

Baskan, G.A. and Erduran, Y. (2009). Reforming education in developing economies of the world: major issues of educational reform in China and Russian Federation. Procedia Social and Behavioral Sciences 1(2019) 347-357.

Corrie, E.M. (1988). Social development and social policy in Guinea: Health and Education 1958-1984. Doctoral thesis.

Diallo, M.S. (2016). The Role of Human Capital in Guinea's Economic Growth: An Empirical Analysis of the

Education Effect on Technological Progress over the period, 1980-2010. A Master's degree thesis.

DFID. (2009). Political economy analysis: How to note. A DFID practice paper. Retrieved from: file://sv-

home01/vol_home01/home/s1730065/Desktop/TOPIC_LR/DEF_Political\%20ECO\%20.pdf

Easterly, W. R. (2005). What did structural adjustment adjust? The association of policies and growth with repeated IMF and World Bank adjustment loans. Journal of Development Economics 76: 1-22.

Harbison, F.H. (1973). Human resources as the wealth of nations. Economic development report. Oxford University Press.

Havelock, R. and Huberman, M. (1977). Solving educational problems: The theory and reality of innovation in developing countries. International Bureau Education Studies and surveys in comparative education. UNESCO.

Hirosato, Y. \& Kitamura, Y. (2009). The political economy of education reforms and capacity development in Southeast Asia. Cases of Cambodia, Laos and Vietnam. Education in the Asia-Pacific Region Series: Issues, Concerns and Prospects: Springer.

Jaramillo, A. and Tietjen, K. (2001). Early childhood development in Africa: Can we

do more for less? A look at the impact and implications of preschools in Cape Verde and Guinea. African Region Human Development Working Paper Series.

Kingdon, J. W. (2002), Agendas, Alternatives, and Public Policies. London: Longman Publishing Group.

Kingdon et al. (2014). A rigorous review of the political economy of education systems in developing countries education. Final report. Rigorous literature review. Department for International Development.

Midling, M., Filion, L., David-Gnahoui, E., Gassama-Mbaye, M., Diallo, A. T., \& Diallo, A. K. (2006). Program evaluation for USAID/Guinea Basic Education Program portfolio. Arlington, VA: DevTech Systems, Inc.

Moulton, J. et al. (2001). Paradigm lost? The implementation of basic education reforms in Sub-Saharan Africa. Washington, D.C.: Technical Paper No. 109, USAID.

OECD High Level Forum (2005). Paris declaration on aid effectiveness: ownership, harmonization, alignment, results and mutual accountability. Paris: OECD.

OECD-DAC. (2006). The challenge of capacity development: working towards good practice. Paris: DAC Network on Good Governance (GOVNET).

Oplatka, I. (2018). Reforming education in developing countries: From neoliberalism to communitarianism. Routledge Research in International and Comparative Education.

Republic of Guinea (2002). Poverty reduction strategy paper. Conakry, Guinea.

République de Guinée. (2017). Secteur de l'éducation. Rapport Annuel de Performance 2016: Exécution du PSE 
intérimaire. Conakry, Guinée.

République de Guinée. (2018). Rapport annuel de performance 2017 du secteur de l'éducation et de la formation (MEN-A-METFP-ET-MESRS). Conakry, Guinée.

Riddell, A.R. (1999a). The need for a multidisciplinary framework for analyzing educational reform in developing countries. International Journal of Educational Development, 19(3): 207-217.

Rivière, C. (1975). Dynamique de la stratification sociale en Guinée. Thèse présentée devant l'université de Paris V le 18 janvier 1975. Lille: Atelier: Reproduction des Thèses Université Lille III.

Robbins, L. (1932) $\left(2^{\text {nd }}\right.$ ed). An essay on the nature and significance of Economic science, London: Macmillan.

Rondinelli, D.A, Middleton, J., and Verspoor, A.M. (1990). Planning education reforms in Developing Countries: The contingency approach. Duke Press Policy Studies. Duke University Press.

Robertson, S. Novelli, M. Dale, R. Tikly, L. Dachi, H. \& Ndebela, A. (2007). Globalisation, education and development: Ideas, Actors and Dynamics. London: DfID.

Robertson, S., Mundy, K., Verger, A., \& Menashy, F. (2012), Public private partnerships in education: New actors and modes of governance in a globalizing world. London: Edward Elgar.

Samoff, J. (1999b). "Education sector analysis in Africa: Limited national control and even less national ownership." International Journal of Educational Development, 19(4-5):249-272.

Saouroumou, K. (2017). Crise à l'éducation Guinéenne: la qualité de l'enseignement indexée par les défenseurs des droits humains. Lexpressguinee.com, retrieved on August 29, 2019 from:

http://www.lexpressguinee.com/fichiers/videos5.php?langue=fr\&idc=fr_Crise_a_l_education_guineenne_la_qualit e_de__enseignement

Steiner-Khamsi, G. (2004). The global politics of educational borrowing and lending. New York: Teachers' College Press.

Steiner-Khamsi, G. (2010). The politics and economics of comparison. Comparative Education Review, 54, (3), 323342.

Swift-Morgan, J.E. (2011). Is good governance rational? The case of post-bureaucratic education system reform in the Republic of Guinea (Doctoral Dissertation).

UNESCO-IBE. (2007b). Pre-service training programmes for 'basic education' teachers: an initial exploration of minimum qualification standards worldwide. Global Monitoring Report.

UNESCO. (2011). CapEFA programme, capacity building for EFA. Translating theory into practice. Paris.

UN-ECA. (2016). Country profile: Guinea. Sub regional Office for West Africa.

USAID-Education Development Center (1998). Primary education in Guinea: limited sector assessment. Improving Educational Quality (IEQ2) Project.

USAID/Guinea. (2006), Program Evaluation for USAID/Guinea Basic Education Program Portfolio.

Verger, A. (2011), Framing and selling global education policy: the promotion of PPPs in education in low-income countries. Journal of Education Policy, doi:10.1080/02680939.2011.623242

Verger et al. (2012). Global education policy and international development: new agendas, issues and policies. Continuum, London.

Verger et al. (2016). The privatization of education. A political economy of global education reform. In G. Steinerkhamsi (ed), International Perspectives on Education Reform.

Walmond, M. (2002). Guinea: to projectize or not to projectize? Two different donor responses to education reform. In J. Moulton, K. Mundy, M. Walmond \& J. Williams (Eds.), Education reforms in Sub-Saharan Africa: Paradigms lost? (pp. 119-148): Greenwood Publishing Group.

Walters, H. (2007). Capacity development, institutional change and theory of change: what do we mean and where are the linkages. Preparatory paper for the seminar "Scrutinizing Success and Failure in Development".

Williams, J.H. and Cummings, W.K. (2005). Policy-making for education reform in Developing Countries: Contexts and Processes, Volume 1. Lanham, MD: Scarecrow Education.

World Bank. (1990). Republic of Guinea country economic memorandum: Sectoral

Analyses. Report No.8774-GUI.

World Bank. (1995). Equity and school improvement: Republic of Guinea. Washington, D.C: The World Bank.

World Bank. (1999). Capacity building for service delivery project: Republic of Guinea. Washington, D.C.: The

World Bank.

World Bank. (2001). Project appraisal document on a proposed credit in the amount of SDR 55.7 million to the Republic of Guinea for an Education for All project: in support of the first phase of the Education for All Program (Project Appraisal Document No. 20405). Washington, DC: The World Bank.

World Bank. (2002). Dimension of economic analysis performed for the sector education program. Washington,

D.C: The World Bank. 
World Bank. (2013). SABER- systems approach for better education results-country report on early childhood development in Republic of Guinea.

World Bank Group. (2018). Republic of Guinea: Overcoming growth stagnation to reduce poverty. Systematic Country Diagnostic. Report No. 123649-GN. 